\title{
EFFECT OF ISCHEMIC PRECONDITIONING ON LIVER ISCHEMIA REPERFUSION INJURY IN AGED RATS
}

\author{
By \\ Gehane M. Hamed, Ansam A. Seif, Manal S. Abd-El-Hamid \\ and Maryam M. El-Masry*
}

Department of Physiology, Faculty of Medicine, Ain Shams University

\begin{abstract}
Background: As the criteria for liver donation have been extended to include marginal donors, liver grafts are becoming particularly vulnerable to hepatic ischemia-reperfusion injury (IRI). However, no specific measures have been validated to ameliorate hepatic IRI.
\end{abstract}

Objective: To investigate the effect of ischemic preconditioning on hepatic ischemia/reperfusion (IR) injury in aged rats.

Materials and Methods: The present study was performed on 45 aged male Wistar rats, weighing at the start of the study between 350-550 g. Animals were randomly divided into the following equal groups: Group I (Sham-operated control group), Group II (Liver ischemia reperfusion group): Rats were subjected to 1-hour partial liver ischemia followed by 24-hour reperfusion and Group III (ischemic preconditioned group): Rats were subjected to brief period of ischemia and reperfusion, then were subjected to hepatic IR as group II. Blood samples were collected and were subjected to measurement of Liver function tests, i.e. serum ALT, AST, liver malondialdehyde and glutathione peroxidase. Also, histopathological study of rat livers was performed.

Results: There were significant decrease in liver weight and liver weight to body weight percent in IR group compared to the sham-operated rats. Upon preconditioning before IR, the liver weights still decreased compared to the sham-operated rats. Liver weight to body weight ratio ameliorated or less decreased in the ratio compared to sham-operated, and significantly increased in the ratio compared to the IR rats. There were significant increases in serum levels of liver enzymes (ALT and AST), at two time points, especially 24 hours after reperfusion as well as significant increase in hepatic MDA level in IR rats. In addition, IR has induced marked liver damage as shown by histopathological examination. Ischemic preconditioning ameliorated liver ischemia reperfusion injury as indicated by marked reduction in the liver enzymes although their levels did not match the levels recorded in the sham-operated rats and hepatic MDA. Hepatic level of GPx showed a significant increase compared to both the sham-operated and IR rats and that was associated with significant improvement of the histopathological examination compared to IR rats.

Conclusion: Ischemic preconditioning ameliorated the hepatic injury associated with ischemia reperfusion. However, future work is needed to explain the mechanism by which IPC ameliorate liver IRI.

Key Words: Liver, ischemic preconditioning, ischemic reperfusion injury.

\section{INTRODUCTION}

With the rise in acute and chronic liver disorders, liver transplantation remains the best choice in the treatment of end stage liver disorders (Liu et al., 2015). Moreover, with advancing age, patients are more likely 


\section{GEHANE M. HAMED et al.}

to acquire hepatic malignancies that are amenable to surgical resection and transplantation (Wang et al., 2011). Hepatic ischemia reperfusion (IR) injury is an unavoidable consequence encountered in the intra and post-operative management of hepatic surgery (Suyavaran and Thirunavukkarasu, 2017).

Minimizing the adverse effects of hepatic IR injury is an important clinical concern; being responsible for up to $10 \%$ of early transplantation failure and graft rejection (De Rougemont et al., 2009). As the liver is a highly aerobic organ, so it is innately vulnerable to hypoxic and ischemic stress, especially in old age due to the significantly lower reparative capacity after IR injury (Wang et al., 2014). Liver IR injury is a phenomenon in which cellular damage due to hypoxia is exacerbated following the return of blood flow and the restoration of oxygen delivery (Xue et al., 2016). The main causes that mediate IR-induced liver injury are increased oxidative stress and inflammation (Ge et al., 2015) and hepatocyte apoptosis induced by mitochondrial dysfunction (Pantazi et al., 2016).

Ischemic Preconditioning (IPC), which involves brief periods of ischemia and reperfusion before prolonged ischemia, was claimed to play a protective role against liver IR injury (Chu et al., 2015) and represents a feasible and reliable tool (Macedo and Miranda, 2010). Figueira et al. (2014) suggested that 10 minutes of ischemia followed by 10 minutes of reperfusion prior to 60 minutes of liver ischemia was able to lower serum liver transaminases and improve the hepatic microcirculation in rat model. Yong et al (2013) reported that 5-10 minutes of ischemic preconditioning prior to 30 minutes of liver ischemia improved liver functions and decreased oxidative stress in a hepato-cirrhosis rat model.

\section{MATERIALS AND METHODS}

The present study was performed on 45 aged male Wistar rats, weighing at the start of the study between 350-550 g. When first arrived at the animal house, rats were acclimatized for 7 days prior to experiments in a plastic cages measured $30 \times 30 \mathrm{~cm}$ with every 3 rats in a cage, and housed a temperature-controlled room $\left(22-28^{\circ} \mathrm{C}\right)$ with normal light/dark cycles. Rats were fed regular meals, introduced daily at 8 a.m., in the form of bread, milk and green vegetables. All rats were treated in accordance with the Guide for Care and Use of Laboratory Animals and the study protocol was approved by the Research Ethical Committee of Faculty of Medicine Ain Shams University.

Rats were initially weighed and randomly distributed into three equal groups:

\section{Group I (Sham-operated control} group): Rats were subjected to laparotomy and closure without vascular clamping.

Group II (Hepatic IschemiaReperfusion group): Rats were subjected to partial liver ischemia (70\%) for 1 hour, followed by 24 hours of reperfusion according to Liu et al. (2016).

Group III (Ischemic-Preconditioned group): Rats were subjected to one cycle of ischemia and reperfusion (10 $\mathrm{min}$ of ischemia and $10 \mathrm{~min}$ of reperfusion) according to Liu et al. (2016) prior to hepatic ischemia-reperfusion (IR) as in group II.

Blood samples were collected into plastic tubes to be centrifuged at $3000 \mathrm{rpm}$ for 15 minutes. Separated serum was 
pipetted into clean aliquots and was stored at $-80{ }^{\circ} \mathrm{C}$ for later determination of serum ALT and AST (Quantitative determination was done by the kinetic method described by Tietz (1995), using kits supplied by SPINREACT, Spain).

Liver was dissected and collected immediately washed with cold saline and dried by filter paper, then liver weight was measured using 5-Digit-Metler balance (AE 163). Liver was divided, blotted by filter paper, wrapped in parafilm layer and stored at $-80{ }^{\circ} \mathrm{C}$ for determination of:

- Oxidative stress marker: Malondialdehyde (MDA), by colorimetric method according to the method described by Satoh (1978), using kits supplied by Bio-diagnostic, Egypt.

- Anti-oxidant enzyme activity: Glutathione peroxidase (GPx), ELISA colorimetric method, using kits supplied by Cloud-Clone Corp, USA.

Histopathological examination: The excised 2-3 mm thick slices of the liver tissue were fixed in $10 \%$ buffered formalin solution immediately after removal for 48 hours. The specimens were dehydrated in ascending grades of alcohol, cleared in xylene and embedded in paraffin. Sections $(4 \quad \mathrm{~m})$ were stained with hematoxylin and eosin (H\&E) and examined by a light microscope.

Statistical Analysis: Results were expressed as means \pm SEM. One-Way ANOVA was used to test for differences among the studied groups followed by LSD (Least Significant Difference) to find intergroup significance. For differences with the same group, student's t-test for paired data Statistical significance was performed by using SPSS (Statistical Program for Social Science) statistical Package (SPSS Inc.) version 20. P value < 0.05 was considered significant.

\section{RESULTS}

As shown in table (1); significant reductions were observed in liver weight and liver weight/ body weight percent in hepatic ischemia-reperfusion (IR), and hepatic ischemic preconditioning (IPC), compared to the sham-operated control group (Sham).

Table (1): Liver weight and Liver to body weight \% ratio in sham-operated control (sham) group, hepatic ischemia reperfusion group (IR), and preconditioned group (IPC).

\begin{tabular}{|c|c|c|c|}
\hline $\begin{array}{ll}\text { Parameters } & \text { Groups } \\
\end{array}$ & $\begin{array}{c}\text { Control Group } \\
\text { (15) }\end{array}$ & $\begin{array}{l}\text { IR Group } \\
\text { (15) }\end{array}$ & $\begin{array}{c}\text { IPC Group } \\
(15)\end{array}$ \\
\hline $\begin{array}{l}\text { Liver weight }(\mathrm{g}) \\
\text { Mean } \pm \text { SEM } \\
\text { a } \\
\text { b }\end{array}$ & $13.30 \pm 0.59$ & $\begin{array}{c}11.31 \pm 0.28 \\
<0.001\end{array}$ & $\begin{array}{c}11.27 \pm 0.34 \\
<0.001 \\
\text { NS }\end{array}$ \\
\hline $\begin{array}{l}\text { Liver weight/body weight } \%(\mathrm{~g}) \\
\text { Mean } \pm \text { SEM } \\
\text { a } \\
\text { b }\end{array}$ & $3.31 \pm 0.19$ & $\begin{array}{c}2.42 \pm 0.09 \\
<0.001\end{array}$ & $\begin{array}{c}2.85 \pm 0.11 \\
<0.05 \\
<0.05\end{array}$ \\
\hline
\end{tabular}

a: Significant difference from Sham-operated control group, by LSD at least $\mathrm{P}<0.05$

b: Significant difference from ischemia-reperfusion group, by LSD at least $\mathrm{P}<0.05$

NS: Non-significant

Between parenthesis: number of rats. 
As shown in table (2), the $24 \mathrm{~h}$ ALT serum level was significantly higher compared to the $1 \mathrm{~h}$ ALT in the IR group $(389.67 \pm 27.39$ vs $236.91 \pm 40.14 \mathrm{U} / \mathrm{L})$, the IPC group (144.94 \pm 16.02 vs $92.25 \pm 14.52$ $\mathrm{U} / \mathrm{L})(\mathrm{P}<0.005, \mathrm{P}<0.05$ respectively). Meanwhile, no significance was noticed between them in the sham-operated group.

Compared to the $1 \mathrm{~h}$ AST, the $24 \mathrm{~h}$ serum level was significantly higher in all studied groups; $(27.64 \pm 1.96$ vs $21.90 \pm 1.74 \mathrm{U} / \mathrm{L}$ in the control group, $469.35 \pm 52.06$ vs $286.37 \pm 37.76 \mathrm{U} / \mathrm{L}$ in the IR group, $183.27 \pm 21.38$ vs $103.70 \pm 13.79$ in the IPC group) $(\mathrm{P}<0.01, \mathrm{P}<0.01$, $\mathrm{P}<0.005$ respectively).

Moreover, in the IR group of rats compared to the sham-operated control group, significant increases were noticed in the serum $1 \mathrm{~h} \& 24 \mathrm{~h}$ ALT levels; $(236.91 \pm 40.14$ vs $17.94 \pm 2.12 \mathrm{U} / \mathrm{L} \&$ $389.67 \pm 27.39$ vs $18.27 \pm 1.35 \mathrm{U} / \mathrm{L})$ and also in the serum $1 \& 24 \mathrm{~h}$ AST levels $(286.37 \pm 37.76$ vs $21.90 \pm 1.74$ U/L\&
$469.35 \pm 52.06 \quad$ vs $27.64 \pm 1.96 \quad \mathrm{U} / \mathrm{L}$ respectively) ( $\mathrm{P}<0.001$ for all $)$.

On the other hand, preconditioning decreased significantly the serum levels of $1 \& 24 \mathrm{~h}$ ALT and $1 \& 24 \mathrm{~h}$ AST compared to the IR group $(92.25 \pm 14.52$ vs $236.91 \pm 40.14 \& \quad 144.94 \quad \pm 16.02$ vs. $389.67 \pm 27.39 \mathrm{U} / \mathrm{L})$ and $(103.70 \pm 13.79$ vs. $286.37 \pm 37.76 \& \quad 183.27 \pm 21.28 \quad$ vs. 469.35 $\pm 52.06 \mathrm{U} / \mathrm{L}$ respectively) $(\mathrm{P}<0.001$ for all).

However, compared to the shamoperated control group the preconditioned group (IPC) displayed a significant increase in both 1 \& $24 \mathrm{~h}$ ALT $(92.25 \pm 14.52$ vs. $17.94 \pm 2.12 \& 144.94 \pm$ 16.02 vs $18.27 \pm 1.35 \mathrm{U} / \mathrm{L}$ respectively) $(\mathrm{P}$ $<0.05, \mathrm{P}<0.001)$. In addition, $1 \& 24 \mathrm{~h}$ AST showed significant elevations compared to the sham group (103.70 \pm 13.79 vs. $21.90 \pm 1.74 \mathrm{U} / \mathrm{L} \& 183.27 \pm$ 21.38 vs $27.64 \pm 1.96 \mathrm{U} / \mathrm{L}$ respectively) (P $<0.01, \mathrm{P}<0.005$ respectively).

Table (2): Mean \pm SEM of serum (1 hour \& 24-hour) Alanine transferase (ALT) \& Aspartate transferase (AST) in the different studied groups.

\begin{tabular}{|c|c|c|c|}
\hline $\begin{array}{ll}\text { Parameters } & \text { Groups } \\
\end{array}$ & $\begin{array}{l}\text { Control } \\
\text { Group }\end{array}$ & $\begin{array}{l}\text { IR } \\
\text { Group }\end{array}$ & $\begin{array}{c}\text { IPC } \\
\text { Group }\end{array}$ \\
\hline $\begin{array}{l}\text { ALT }(1 \mathrm{~h}, \mathrm{U} / \mathrm{L}) \\
\text { Mean } \pm \text { SEM } \\
\text { a } \\
\text { b }\end{array}$ & $\begin{array}{c}(13) \\
17.94 \pm 2.12\end{array}$ & $\begin{array}{c}(11) \\
236.91 \pm 40.14 \\
P<0.001\end{array}$ & $\begin{array}{c}(12) \\
92.25 \pm 14.52 \\
P<0.05 \\
P<0.001\end{array}$ \\
\hline $\begin{array}{l}\text { ALT }(24 \mathrm{~h}, \mathrm{U} / \mathrm{L}) \\
\text { Mean } \pm \text { SEM } \\
\text { a } \\
\text { b } \\
\text { c }\end{array}$ & $\begin{array}{c}(11) \\
18.27 \pm 1.35\end{array}$ & $\begin{array}{c}(12) \\
389.67 \pm 27.39 \\
\mathbf{P}<0.001 \\
P<0.005\end{array}$ & $\begin{array}{c}(8) \\
144.94 \pm \mathbf{1 6 . 0 2} \\
P<0.001 \\
P<<0.001 \\
P<0.05\end{array}$ \\
\hline $\begin{array}{l}\text { AST }(1 \mathrm{~h}, \mathrm{U} / \mathrm{L}) \\
\text { Mean } \pm \text { SEM } \\
\text { a } \\
\text { b }\end{array}$ & $\begin{array}{c}(14) \\
21.90 \pm 1.74\end{array}$ & $\begin{array}{c}(12) \\
286.37 \pm 37.76 \\
P<0.001\end{array}$ & $\begin{array}{c}(12) \\
103.70 \pm 13.79 \\
P<0.01 \\
P<0.001 \\
\end{array}$ \\
\hline $\begin{array}{l}\text { AST }(24 \mathrm{~h}, \mathrm{U} / \mathrm{L}) \\
\text { Mean } \pm \text { SEM } \\
\text { a } \\
\text { b } \\
\text { c }\end{array}$ & $\begin{array}{c}(11) \\
27.64 \pm 1.96\end{array}$ & $\begin{array}{c}(12) \\
469.35 \pm 52.06 \\
P<0.001 \\
P<0.01\end{array}$ & $\begin{array}{c}(10) \\
183.27 \pm \mathbf{2 1 . 3 8} \\
\mathbf{P}<0.005 \\
\mathbf{P}<0.001 \\
P<<0.005\end{array}$ \\
\hline
\end{tabular}

a: Significant difference from Sham-operated control group, by LSD at least $\mathrm{P}<0.05$

b: Significant difference from ischemia-reperfusion group, by LSD at least $\mathrm{P}<0.05$

c: Significance of difference between $1 \mathrm{~h}$ and $24 \mathrm{~h}$ ALT and AST level by Student's " $\mathrm{t}$ " test for paired data.

NS: Non-significant Between parenthesis: number of rats. 
Data showed in table (3), revealed a significant increase in MDA level (43.02 \pm 3.05 vs. $25.06 \pm 1.64 \mathrm{ng} / \mathrm{ml})(\mathrm{P}<0.001)$, and a non-significant reduction of hepatic GPx in IR group as compared to that of the sham operated group.

Preconditioning induced a remarkable protection against peroxidative damage caused by ischemia-reperfusion evidenced by the significant decrease in the hepatic MDA level compared to the correspond- ing value in IR group $(30.38 \pm 1.65$ vs $43.02 \pm 3.05 \mathrm{ng} / \mathrm{ml}) \quad(\mathrm{P}<0.001)$, while it showed non significantly change compared to normal control group $(30.38 \pm 1.65$ vs. $25.06 \pm 1.64 \mathrm{ng} / \mathrm{ml})$. Also, IPC group provoked a significant rise in GPx level $(6.48 \pm 0.59 \mathrm{ng} / \mathrm{ml}$ vs. $4.39 \pm 0.42 \mathrm{ng} / \mathrm{ml}$ in the IR and $5.01 \pm 0.45 \mathrm{ng} / \mathrm{ml}$ in the sham group) ( $\mathrm{P}<0.05$ and $\mathrm{P}<0.005$ respectively).

Table (3): Mean \pm SEM of liver MDA and GPx in the different studied groups.

\begin{tabular}{|l|c|c|c|}
\hline Groups & $\begin{array}{c}\text { Control Group } \\
(15)\end{array}$ & $\begin{array}{c}\text { IR Group } \\
(14)\end{array}$ & $\begin{array}{c}\text { IPC Group } \\
(14)\end{array}$ \\
\hline $\begin{array}{l}\text { MDA (ng/ml) } \\
\text { Mean } \pm \text { SEM }\end{array}$ & $25.06 \pm 1.64$ & $\begin{array}{c}43.02 \pm 3.05 \\
\text { P }\end{array}$ & $\begin{array}{c}30.38 \pm 1.65 \\
\text { NS }\end{array}$ \\
b & & $\mathbf{P}<0.001$ \\
\hline GPx (ng/ml) & & $4.39 \pm 0.42$ & $\begin{array}{c}\mathbf{6 . 4 8} \pm 0.59 \\
\mathbf{P}<0.05\end{array}$ \\
$\begin{array}{l}\text { Mean } \pm \text { SEM } \\
\text { b }\end{array}$ & $5.01 \pm 0.45$ & NS & $\mathbf{P}<0.005$ \\
\hline
\end{tabular}

a: Significant difference from Sham-operated control group, by LSD at least $\mathrm{P}<0.05$

b: Significant difference from ischemia-reperfusion group, by LSD at least $\mathrm{P}<0.05$

NS: Non-significant

Between parenthesis: number of rats.

Histopathological Report: In sham group, the liver tissues were well structured and showed the normal histological structure of hepatic lobule traversed by a central vein and peripherally-situated portal areas containing bile duct and branches of hepatic artery and portal vein. However, as shown in figure (1), IR group liver sections revealed marked abnormalities in morphology at $24 \mathrm{~h}$ after reperfusion, including marked cytoplasmic vacuolization of hepatocytes (steatosis of hepatocytes), moderate sinusoidal congestion. In addition, there was an evidence of moderate kupffer cell activation, mild portal infiltration with inflammatory cells and mild sinusoidal leukocytosis.

Following preconditioning, examined liver sections showed decrease in the cytoplasmic vacuolization of hepatocytes and congestion compared to the IR group. Moreover, there was marked decrease in the portal infiltration with the inflammatory cells and sinusoidal leukocytosis. On the other hand, the kupffer cell activation remained as the IR group. 


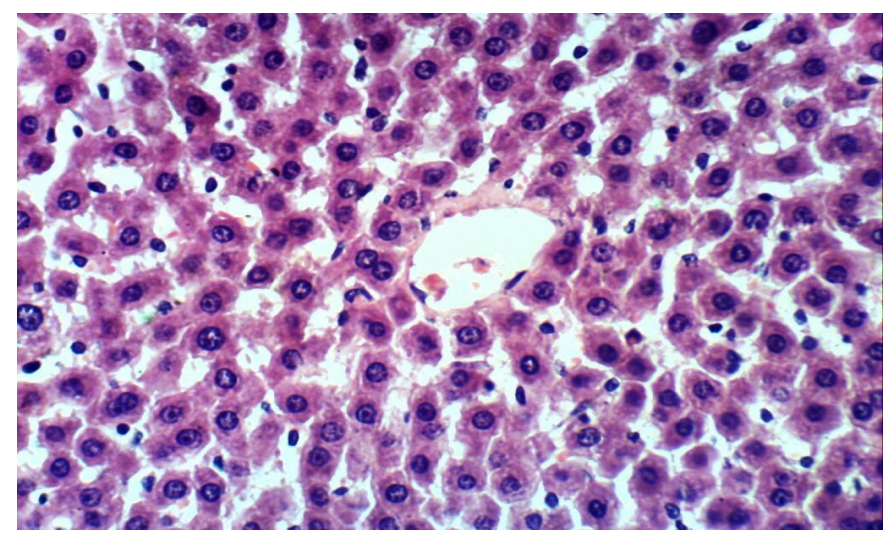

Figure (1): Liver of rat from sham operated group showing the normal histological structure of hepatic lobule (H\&E X 400).

A)

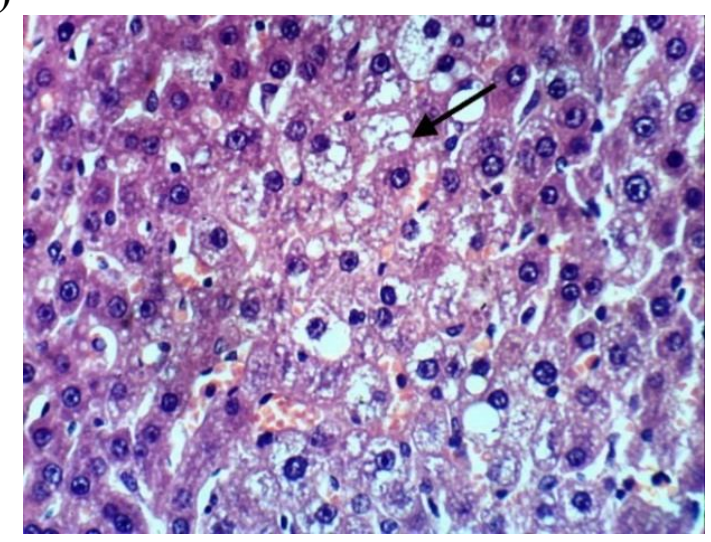

C)

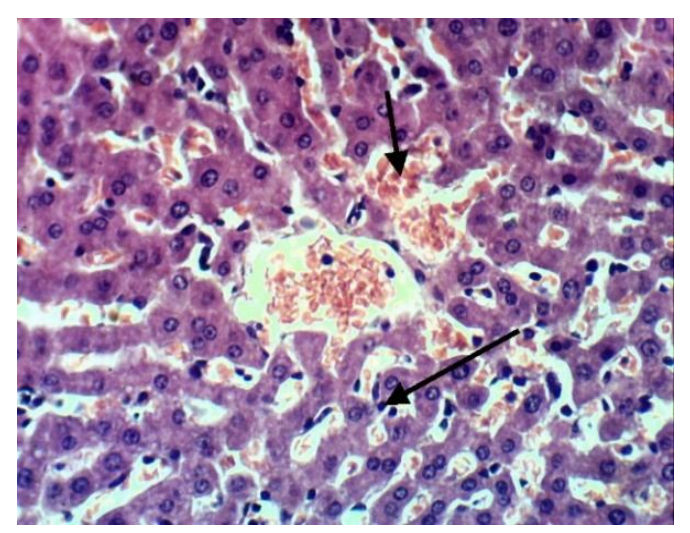

B)

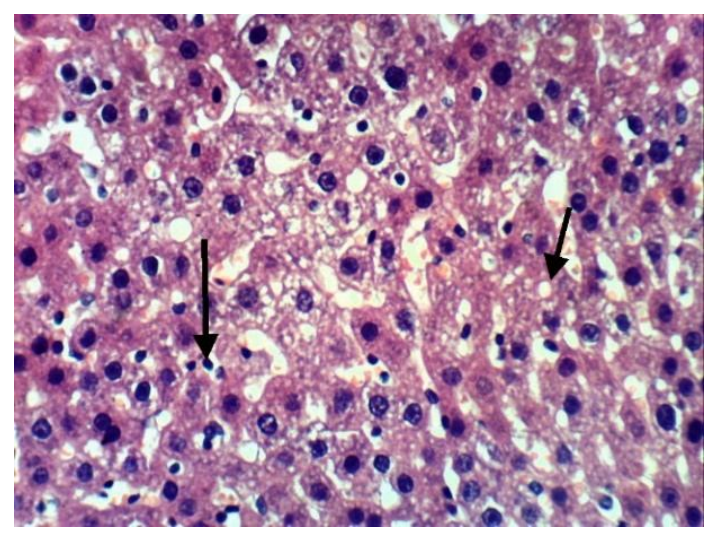

Figure (2): Liver from IR group showing: A) steatosis of hepatocytes B) steatosis of hepatocytes and activation of Kupffer cells $\mathbf{C}$ ) congestion of central vein and hepatic sinusoids as well as activation of Kupffer cells (H\&E X 400). 
A)

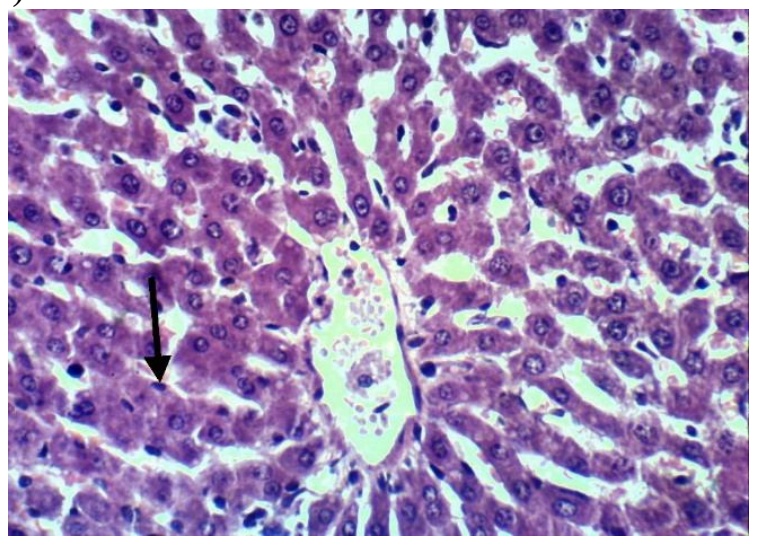

B)

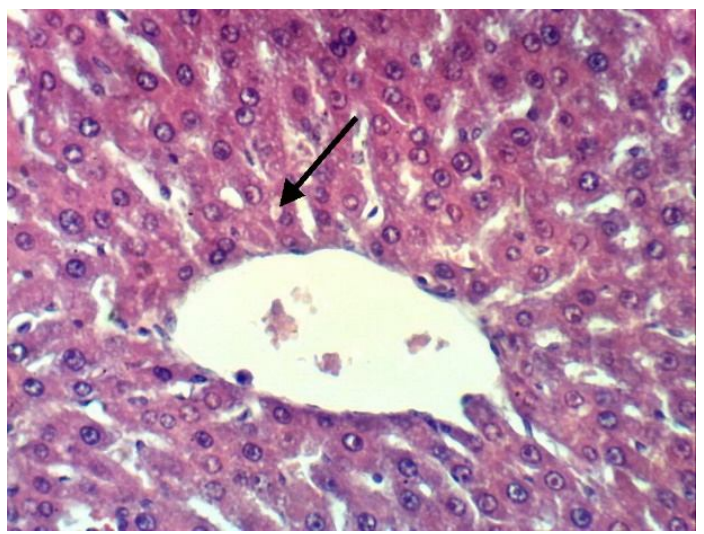

Figure (3): Liver from IPC group showing: A) showing Kupffer cells activation B) slight cytoplasmic vacuolization of some hepatocytes (H\&E X 400).

\section{DISCUSSION}

In this study, all studied groups compared to the control showed significant decreases in liver weights and liver weight to body weight $\%$ ratio. Compared to the corresponding values in the control group, the ischemia reperfusion (IR) group of rats revealed dramatic elevations in serum levels of liver enzymes (ALT) and (AST), at two time points, after 1 hour and 24 hours after reperfusion as well as significant increase in hepatic (MDA) level and nonsignificant change in hepatic (GPx) level. In addition, IR has induced marked liver damage as shown by histopathological examination. Upon preconditioning prior to IR, marked reduction was observed in the liver enzymes compared to IR rats. However, their levels did not match the levels recorded in shamoperated rats, while hepatic (MDA) levels showed significant reduction compared to IR rats to match the levels recorded in sham operated rats, whereas hepatic level of (GPx) showed significant increase compared to IR and sham-operated rats that were associated with a significant improvement of the histopathological picture of hepatocytes necrosis and inflammatory cells infiltration.

The decrease in the liver weight associated with IR and IPC may be related to the liver damage induced by IR injury. The IR procedure might cause reduction in the DNA synthesis rate and might affect recovery of liver weight after ischemia (Helling, 2006). TNF- $\alpha$ may play a role in liver regeneration (Shuh et al., 2013). A potential role for TNF- $\alpha$ in liver regeneration is indicated by the work of B?hm et al. (2010) who showed that TNF antibodies may delay and diminish DNA synthesis in regenerating rat liver.

The extent of liver injury in IR is normally assessed by elevated levels of liver enzymes; ALT and AST concentrations (Akashi et al., 2010; Jaeschke \& Lemasters. 2010; and Wang et al., 2011). It has been used to identify liver injury for more than 50 years (Zhou 
et al., 2008 and Peveling-Oberhag \& Zeuzem, 2010).

In the current study, significant increases in serum ALT and AST activities were observed in rats subjected to IR when compared with their respective control rats. These results were in agreement with the previously reported data by Jaeschke \& Lemasters (2010) and Wang et al. (2011) and These data were explained by Ambros et al. (2007) and Yildiz et al. (2008) who declared that the increased levels of ALT and AST could potentially be attributed to the release of these enzymes from the cytoplasm into the blood circulation after rupture of the plasma membrane and cellular damage.

Moreover, several factors may share in injuries associated with hepatic IR such as anerobic metabolism, mitochondria dysfunction, oxidative stress and intracellular calcium overload (Guan et al., 2014). During hepatic ischemia, the metabolic pattern is shifted to anerobic, and intracellular ATP is rapidly depleted. After reperfusion, the $\mathrm{pH}$ values are restored to normal, leading to the activation of proteases and phospholipases and further worsening the damage of tissues and organs (Datta et al., 2013).

Lai et al. (2010) also reported that peroxidative damage increases discharge of hepatic intracellular enzymes and electrolytes. Thus, calcium will get into the cells and accumulate to cause liver injury and hence, enzymes from hepatocytes are released into the circulation, resulting in acute elevation of serum ALT and AST.

Cytokines such as interleukin 1 (IL-1), tumor necrosis factor- $\alpha$ (TNF- $\alpha)$, vascular endothelial growth factor (VEGF), and hepatocyte growth factor (HGF) released from activated Kupffer cells, and neutrophils promote leukocyte activation, and may aggravate liver damage and add to the rise in ALT and AST (Chouillard et al., 2010).

In the present study, IPC prior to IR, markedly improved survival, and significantly suppressed the elevation of ALT and AST levels reflecting a decrease in the destructive effect of IR. These findings were in agreement with Liu et al. (2014) and Theodoraki et al. (2016) who concluded the hepatoprotective effect of IPC from IR injury, and that IPC prolonged survival and increased resistance to liver injury after total hepatic ischemia in mouse and suppressed the elevation of ALT and liver necrosis area induced by IR injury. Moreover, after IPC, cell damage was markedly reduced, although not completely, prevented by the IPC procedure as previously reported by Liu et al. (2014).

Figueira et al. (2014) suggested that 10 minutes of ischemia followed by 10 minutes of reperfusion prior to 60 minutes of liver ischemia was able to lower serum liver transaminases and improve the hepatic microcirculation in rat model. Data reported by Robertson et al. (2017) were also in agreement with the present study as regard the decrease in ALT and AST levels, indicating a clear hepatoprotective effect against IR injury.

Measurement of MDA levels is used widely as an indicator of lipid peroxidation (Adam, 2014). MDA results from the peroxidation of biological membrane polyunsaturated fatty acid (PUFA) (Osman et al., 2017). ROS 
degrades lipids forming MDA, which is a reactive aldehyde that reacts with deoxyadenosine and deoxyguanosine in DNA causing toxic stress in cells (Osman et al., 2017). MDA is used as a biomarker to measure the level of oxidative stress in tissues (Khoubnasabjafari et al., 2015).

The oxidative markers showed significant elevations in hepatic MDA levels in IR rats when compared to sham operated rats. After preceding the IR with IPC, their values significantly decreased from their respective IR rats and became insignificant from the sham operated rats, denoting successful decline of oxidative stress by IPC.

These results were in accordance with previous studies which showed an elevation in hepatic MDA after IR of liver (Wang et al., 2011 and Pérez et al., 2016). In addition, the results reported by Adam. (2003) showed that MDA levels in liver tissue elevated significantly after brain IR in rats, indicating that the function of the liver, although a remote organ was damaged.

The increased hepatic MDA with IR observed in the present study was a convenient marker of enhanced lipid peroxidation. Lipid peroxidation is known to be responsible for cell membrane damage, and has been implicated in the pathogenesis of IR injury (Zhou et al., 2009).

Reactive oxygen species (ROS) have been considered a major deleterious factor in reperfusion injury (Granger and Kvietys, 2015). ROS initiates cell damage through the two major mechanisms of covalent binding to cell membrane lipids and lipid peroxidation (Barrera, 2012). It has been believed that free radicals initiate lipid peroxidation of unsaturated fatty acid of cell membranes (Lai et al., 2010). In addition, oxidative stress may cause reversible and/or irreversible modifications of sensitive proteins (Dahl et al., 2015). These oxidative modifications may lead to increased susceptibility to proteolytic attacks (Dahl et al., 2015). Kupffer cells and hepatocytes also generate ROS, leading to direct damage of endothelial cells and hepatocytes (Kuboki et al., 2009).

On the other hand, hepatic glutathione peroxidase (GPx) level, the widely studied among the endogenous antioxidants was non significantly changed in the IR rats compared to the control rats. IPC rats showed a significant increase in the GPx level compared to IR and sham-operated rats. These changes came in agreement with Osman et al. (2017) who reported reduced MDA and increased antioxidant enzymes levels following IPC. Moreover, Vaghasiya et al. (2010) showed that IPC increased the expression and activity of antioxidant enzymes in the ischemic kidney and liver.

ROS levels are tightly regulated through different pathways and the major regulators are ROS scavengers that include superoxide dismutase (SOD), catalase, and glutathione peroxidase (GPx) (Kuboki et al., 2009). Liver IR depleted the intracellular antioxidant glutathione stores in the liver and plasma. Glutathione acts by directly scavenging ROS and also by being a cofactor for GPx-catalyzed reactions that degrade hydrogen peroxide (Espinosa-Diez et al., 2015). 


\section{GEHANE M. HAMED et al.}

The aging-related changes including increased oxidative stress, increased inflammatory response, accelerated cellular senescence, and progressive organ dysfunction significantly affect cellular responses to injury (Poulose and Raju, 2014). Furthermore, aging-associated decline in mitochondrial function has been shown to enhance the vulnerability to injury (Kim et al., 2015). Aging alters stress-induced expression of heme oxygenase 1 in a cell specific manner, which may contribute to the diminished stress tolerance observed in older organisms (Bloomer et al., 2009).

Furthermore, as proposed by Sheedfer et al. (2013), the aging process is driven by an unbalanced stimulation/response of the immune system, characterized by increased levels of inflammatory markers such as cytokines, chemokine, reactive oxygen species (ROS), as well as decreased levels of antioxidant enzymes.

Ischemic preconditioning is reported to confer organ protection against subsequent ischemia/ reperfusion injury in an endogenous protective mechanism, especially in steatotic livers (Liu et al., 2016). IPC selectively induces e-NOS activity in sinusoidal cells, thus stimulating increased production of NO in the hepatic vasculature (Bj?rnsson et al., 2014). This increase in the NO level also contributes to the physiological responses in liver transplants, i.e. improved hepatic microcirculation by virtue of the elevated NO induced vasodilation and improved tissue oxygenation which promote the resistance against IR induced damage (Abu-Amara et al., 2012). The protective effect of IPC in the liver transplants against IR induced damage has also been attributed to its conservative action on hepatic ATP, tolerance to mitochondrial permeability transition and preservation of ATP synthase activity, and thus tolerates the IR induced lowering of ATP (Rolo et al., 2009).

Richards et al. (2010) and Liu et al. (2014) claimed that IPC could improve antioxidant defenses by activating heme oxygenase-1 (HO-1), an enzyme with antioxidant properties, which is constitutively expressed in hepatocytes, endothelial cells, and stellate cells. Interestingly, although HO-1 is upregulated by IPC, but this increase takes several hours $(24 \mathrm{~h})$ and may not be the earliest protective mechanism of IPC (Datta et al., 2014). In addition, IPC induces the production of other antioxidant enzymes such as superoxide dismutase (Guo et al., 2011 and Yong et al., 2013).

Moreover, it was reported by some authors that IPC may improve liver microcirculation and reduce hepatocellular apoptosis and necrosis through stimulation of HO-1, adenosine receptor and hypoxia-inducible factor (HIF)-1 that activates several hypoxia-responsive genes and increase NO production (Kuo et al., 2016). NO can inhibit TNF- $\alpha$, interleukin-1 $\beta$ (IL-1 $\beta$ ), and oxidative damage by increasing the antioxidants (Miyake et al., 2013).

It is worth mentioning that the significant increases in hepatic MDA and without significant change in hepatic GPx levels in the current study in IR rats, point to a disequilibrium between the oxidant and antioxidant balance, suggesting that liver injury induced by IR could be ascribed to enhancing the oxidative stress. 
Furthermore, the present study suggested that one of the protective effects of IPC against hepatic IR injury was related to their role in reducing tissue oxidative stress levels and that IPC offered protection by increasing GPx activity.

Also, during the short reperfusion phase of IPC, little amounts of ROS are generated that can activate redox-sensitive intracellular signaling pathways, which may protect the liver cells through the inhibition of cell death pathways and simulation of antioxidant (Osman et al., 2017).

The biochemical observations recorded in the current study were supported by the histopathological examination of liver. IR liver showed structural disruption, sinusoidal congestion, hepatocyte ballooning, areas of necrosis, and polymorphonuclear cells enrichment in liver tissues. These histopathological insults were in agreement with Kuo et al. (2016) and Liu et al. (2014). IPC significantly alleviated hepatocyte necrosis and inflammation after IR. These results indicated that IPC can effectively reduce hepatic IR injury in rats.

\section{CONCLUSION}

IPC could ameliorate liver IR injury, which may be a potential target for the treatment or prevention of organ and tissue injuries by IR, and may be promising in the setting of transplantation.

\section{RECOMMENDATION}

More studies are required to elucidate the mechanism (s) involved in IPC.

\section{ACKNOWLEDGMENT}

Special thanks to Prof. Dr. Manal Salman, Professor of Pathology, Faculty of Medicine, Ain Shams University, for her cooperation in the histopathological examination.

\section{REFERENCES}

1. Abu-Amara, M., Yang, S.Y., Seifalian, A., Davidson, B. and Fuller, B. (2012): The nitric oxide pathway-evidence and mechanisms for protection against liver ischemia reperfusion injury. Liver Int, 32(4): 531-543.

2. Adam, A.N.I. (2014): Some mechanisms of the protective effect of ischemic preconditioning on rat liver ischemia-reperfusion injury. International Journal of General Medicine, 7: 483-489.

3. Akachi, T., Shiina, Y., Kawaguchi, T., Kawagishi, H., Morita, T. and Sugiyama, K. (2010): 1-methylmalate from camu-camu (Myrciaria dubia) suppressed D-galactosamineinduced liver injury in rats. Biosci Biotechnol Biochem; 74: 573-578.

4. Ambros, J.T., Herrero-Fresneda, I., Borau, O.G. and Boira, J.M. (2007): Ischemic preconditioning in solid organ transplantation: from experimental to clinics. Transpl Int., 20: 219-229.

5. Barrera, G. (2012): Oxidative Stress and Lipid Peroxidation Products in Cancer Progression and Therapy. ISRN Oncology, 2012, 137289.

6. Bj?rnsson, B., Winbladh, A., Bojmar, L., Sundqvist, T., Gullstrand, P. and Sandstr?m, P. (2014): Conventional, but not remote ischemic preconditioning, reduces iNOS transcription in liver ischemia/reperfusion. World Journal of Gastroenterology: WJG, 20(28): 9506-9512.

7. Bloomer, S.A., Zhang, H.J., Brown, K.E. and Kregel, K.C. (2009): Differential regulation of hepatic heme oxygenase-1 protein with aging and heat stress. J Gerontol A Biol Sci Med Sci.,64:419-425.

8. B?hm, F., K?hler, U.A., Speicher, T., and Werner, S. (2010): Regulation of liver 
regeneration by growth factors and cytokines. EMBO Molecular Medicine, 2(8): 294-305.

9. Chouillard, E.K., Gumbs, A.A. and Cherqui, D. (2010): Vascular clamping in liver surgery: physiology, indications and techniques. Ann. Surg. Innov. Res., 4: 2-7.

10. Chu, M.J., Vather, R., Hickey, A.J., Phillips, A.R. and Bartlett, A.S. (2015): Impact of ischemic preconditioning on outcome in clinical liver surgery: a systematic review. BioMed Research International, 2015: 370451.

11. Dahl, J.U., Gray, M.J., and Jakob, U. (2015): Protein Quality Control Under Oxidative Stress Conditions. Journal of Molecular Biology, 427(7):1549-1563.

12. Datta, G., Fuller, B.J. and Davidson, B.R. (2013): Molecular mechanisms of liver ischemia reperfusion injury: insights from transgenic knockout models. World Journal of Gastroenterolog, 19 (11): 1683-1698.

13. Datta, G., Luong, T.V., Fuller, B.J. and Davidson, B.R. (2014): Endothelial nitric oxide synthase and heme oxygenase- 1 act independently in liver ischemic preconditioning. J. Surg. Res., 186: 417-428.

14. Davey, M.W., Stals, E., Panis, B., Keulemans, J. and Swennen, R.L. (2005): Highthroughput determination of malondialdehyde in plant tissues. Anal. Biochem., 347: 201-207.

15. De Rougemont, O., Breitenstein, S., Leskosek, B., Weber, A., Graf R., Clavien, P.A. and Dutkowski, P. (2009): One-hour hypothermic oxygenated perfusion (HOPE) protects nonviable liver allografts donated after cardiac death. Annals of Surgery, 250: 674683.

16. Espinosa-Diez, C., Miguel, V., Mennerich, D., Kietzmann, T., S?nchez-Pérez, P., Cadenas, S., and Lamas, S. (2015): Antioxidant responses and cellular adjustments to oxidative stress. Redox Biology, 6: 183-197.

17. Figueira, E.R., Rocha-Filho, J.A. and Nakatani, M. (2014): Hepatic ischemic preconditioning increases portal vein flow in experimental liver ischemia reperfusion injury.
Hepatobiliary Pancreatic Diseases international, 13(1): 40-47.

18. Granger, D.N. and Kvietys, P.R. (2015): Reperfusion injury and reactive oxygen species: The evolution of a concept. Redox Biology, 6: 524-551.

19. Guan, L.Y., Fu, P.Y., Li, P.D., Li, Z.N., Liu, H.Y., Xin, M.G., and Li, W. (2014): Mechanisms of hepatic ischemia-reperfusion injury and protective effects of nitric oxide. World Journal of Gastrointestinal Surgery, 6(7): 122-128.

20. Guo, J.Y., Yang, T., Sun, X.G., Zhou, N.Y., Li, F.S., Long, D. and Feng, L. (2011): Ischemic postconditioning attenuates liver warm ischemia-reperfusion injury through AkteNOS-NO-HIF pathway. Journal of Biomedical Science, 18(1), 79.

21. Helling, T.S. (2006): Liver failure following partial hepatectomy. HPB: The Official Journal of the International Hepato Pancreato Biliary Association, 8(3):165-174.

22. Jaeschke, H. and Lemasters, J.J. (2010): Apoptosis versus oncotic necrosis in hepatic ischemia/reperfusion injury. Gastroenterology, 125: 1246-1257.

23. Khoubnasabjafari, M., Ansarin, K., and Jouyban, A. (2015): Reliability of malondialdehyde as a biomarker of oxidative stress in psychological disorders. BioImpacts, 5(3):123127.

24. Kim, H., Kisseleva, T. and Brenner, D.A. (2015): Aging and liver disease. Current Opinion in Gastroenterology, 31(3): 184-191.

24. Kuboki, S., Sakai, N., Tsch?p, J., Edwards, M. J., Lentsch, A. B. and Caldwell, C. C. (2009): Distinct contributions of $\mathrm{CD}^{+} \mathrm{T}$ cell subsets in hepatic ischemia/reperfusion injury. American Journal of Physiology Gastrointestinal and Liver Physiology, 296(5): 1054-1059.

26. Kuo, S., Liu, Y., Tsai, C. and Sheen-Chen, S. (2016): Ischemic preconditioning in hepatic ischemic-reperfusion injury. Formosan $J$. Surg., 49: 169-173.

27. Lai, T.Y., Weng, Y.J., Kuo, W.W., Chen, L.M., Chung, Y.T., Lin, Y.M., Tsai, F.J., 
Lee, C.H., Choong, Y.M., Lai, E.Y., Huang, C.Y., and Yeh, Y.L. (2010): Tang ameliorates acute liver injury induced by carbon tetrachloride in rats. Zhong Xi Yi Jie He Xue Bao, 8: 49-55.

28. Liu, A., Fang, H., Wei, W., Dirsch, O., and Dahmen, U. (2014): Ischemic Preconditioning Protects Against Liver Ischemia/Reperfusion Injury via Heme Oxygenase-1-Mediated Autophagy. Critical Care Medicine, 42(12): e762-e771.

29. Liu, A., Huang, L., Fan, H., Fang, H., Yang, Y., Liu, S., Hu, J., Hu, Q., Dirsch, O. and Dahmen, U. (2015): Baicalein pretreatment protects against liver ischemia/reperfusion injury via inhibition of NF- $\mathrm{B}$ pathway in mice. International immunopharcology, 24(1): 72-79.

30. Liu, A., Huang, L., Guo, E., Li, R., Yang, J., Li, R., Yang, Y., Liu, S., Hu, J., Jiang, X., Dirsch, O., Dahmen, A. and Suna, J. (2016): Baicalein pretreatment reduces liver ischemia/reperfusion injury via induction of autophagy in rats. Scientific Reports, 6: $78372-$ 78386.

31. Macedo, F.L. and Miranda, L.E. (2010): Role of Ischemic Preconditioning in Liver Transplant: Experimental and Clinical Transplantation, 1: 1-3.

32. Miyake, T., Yokoyama, Y., Kokuryo, T., Mizutani, T., Imamura, A. and Nagino, M. (2013): Endothelial nitric oxide synthase plays a main role in producing nitric oxide in the superacute phase of hepatic ischemia prior to the upregulation of inducible nitric oxide synthase. J. Surg. Res., 183: 742-751.

33. Osman, A.S., Osman, A.H. and Kamel, M.M. (2017): Study of the protective effect of ischemic and pharmacological preconditioning on hepatic ischemic reperfusion injury induced in rats. JGH Open, 1: 105-111.

34. Pantazi, E., Bejaoui, M., Folch-Puy, E., Adam, R. and Rosell?-Catafau, J. (2016): Advances in treatment strategies for ischemia reperfusion injury. Expert Opin Pharmacother, 17:169-179.

35. Pérez, J.C., Ram?rez, A., Gonz?lez, L., Mu?oz, L. E., Perales, M. M., Alarc?n, G. and Pérez, P. (2016): Spironolactone Effect in Hepatic Ischemia/Reperfusion Injury in Wistar Rats. Oxidative Medicine and Cellular Longevity, 2016, 3196431-3196440.

36. Peveling-Oberhag, J. and Zeuzem, S. (2010): Liver enzymesinterpretation of laboratory values. Versicherungsmedizin, 62: 73-77.

37. Poulose, N., and Raju, R. (2014): Aging and Injury: Alterations in Cellular Energetics and Organ Function. Aging and Disease, 5(2): 101108.

38. Richards, J.A., Wigmore, S.J. and Devey, L.R. (2010): Heme oxygenase system in hepatic ischemia-reperfusion injury. World $J$ Gastroenterol, 16(48): 6068-6078.

39. Robertson, F.P., Fuller, B.J., and Davidson, B.R. (2017): An Evaluation of Ischemic Preconditioning as a Method of Reducing Ischemia Reperfusion Injury in Liver Surgery and Transplantation. Journal of Clinical Medicine, 6 (7): 69.

40. Rolo, A.P., Teodoro, J.S., Peralta, C., Rosello, C.J. and Palmeira, C.M. (2009): Prevention of $\mathrm{I} / \mathrm{R}$ injury in fatty livers by ischemic preconditioning is associated with increased mitochondrial tolerance: the key role of ATP synthase and mitochondrial permeability transition. Transpl Int., 22(11): 10811090.

41. Romanque, P., D?az, A., Tapia, G., UribeEchevarr?, S., Videla, L.A. and Fernandez, V. (2010): Delayed ischemic preconditioning protects against liver ischemia-reperfusion injury in vivo. Transplant Proc., 42:15691575.

42. Satoh, K. (1978): Serum lipid peroxide in cerebrovascular disorders determined by a new colorimetric method. Clin Chim Acta, 90: 3743.

43. Selzner, M., Camargo, C. and Clavien, P. A. (1999): Ischemia impairs liver regeneration following major tissue loss in the rodent. Hepatology, 30: 469-475.

44. Sheedfar, F., Biase, S. D., Koonen, D. and Vinciguerra, M. (2013): Liver diseases and aging: friends or foes?. Aging Cell, 12: 950954. 
45. Shuh, M., Bohorquez, H., Loss, G.E. and Cohen, A.J. (2013): Tumor Necrosis Factor- $\alpha$ : Life and Death of Hepatocytes During Liver Ischemia/Reperfusion Injury. The Ochsner Journal, 13(1):119-130.

46. Suyavaran, A. and Thirunavukkarasu, C. (2017): Preconditioning methods in the management of hepatic ischemia reperfusioninduced injury: Update on molecular and future perspectives. Hepatology Research, 47: 31-48.

47. Theodoraki, K., Karmaniolou, I., Tympa, A., Tasoulis, M.-K., Nastos, C., Vassiliou, I. and Smyrniotis, V. (2016): Beyond Preconditioning: Postconditioning as an Alternative Technique in the Prevention of Liver IschemiaReperfusion Injury. Oxidative Medicine and Cellular Longevity, 2016, 8235921.

48. Tietz, N. W., et al. (1995): Clinical Guide to Laboratory Tests, 3rd ed AACC, Saunders W.B., Philadelphia, PA.

49. Vaghasiya, J.D., Sheth, N.R., Bhalodia, Y.S. and Jivani, N.P. (2010): Exaggerated liver injury induced by renal ischemia reperfusion in diabetes: effect of exenatide. Saudi J Gastroenterol.,16:174-180.

50. Wang, J.H., Behrns, K., Leeuwenburgh, C. and Kim, J.S. (2011): Critical role of autophagy in ischemia/reperfusion injury to aged livers. Autophagy, 8(1): 140-141.

51. Wang, Y., Shen, J., Xiong, X., Xu, Y., Zhang, H., Huang, C., Tian, Y., Jiao, C.,
Wang, X. and Li, X. (2014): Remote ischemic preconditioning protects against liver ischemiareperfusion injury via heme oxygenase-1induced autophagy. PLOS ONE, 9(6): e98834.

52. Xue, T.M., Tao, L.D., Zhang, J., Zhang, P.J., Liu, X., Chen, G.F. and Zhu, Y.J. (2016): Intestinal ischemic preconditioning reduces liver ischemia reperfusion injury in rats. Mol Med Rep.,13(3): 2511-2517.

53. Yildiz, F., Coban, S., Terzi, A., Ates, M., Aksoy, N., Cakir, H. and Bitiren, M. (2008): Nigella sativa relieves the deleterious effects of ischemia reperfusion injury on liver. World Journal of Gastroenterology, 14(33), 5204-5209.

54. Yong, J., Bo, Y., Bao-qiang, W., Tang, J.T. and Zhen, Q. (2013): The Optimal Time Window of Ischemic Preconditioning (IPC) on the Reperfusion Injury in Moderate to Severe Hepatocirrhosis in Rats. Annals of Clinical \& Laboratory Science, 43 (1):64-69.

55. Zhou, G., Dada, L.A., Wu, M., et al. (2009): Hypoxia induced alveolar epithelialmesenchymal transition requires mitochondrial ROS and hypoxia-inducible factor 1. Am J Physiol Lung Cell Mol Physiol., 297: L1120L1130.

56. Zhou, Y., Park, C.M., Cho, C.W. and Song, Y.S. (2008): Protective effect of pinitol against D-galactosamine-induced hepatotoxicity in rats fed on a high-fat diet. Biosci Biotechnol Biochem,72: 1657-1666. 


\section{تأثير التهيئة المسبقة للإقفار على أضرار التووية بعد الإقفار فى كبد

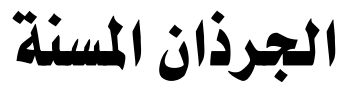

جيهان محمود حامد، أنسام على سيف، منال سعيد عبد الحميد، مريم مسعد المصرى قسم الفسيولوجيا الطبية، كلية الطب، جامعة عين شمس لمسئ

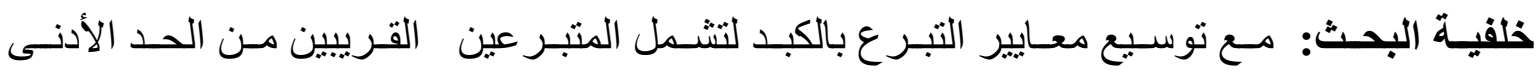

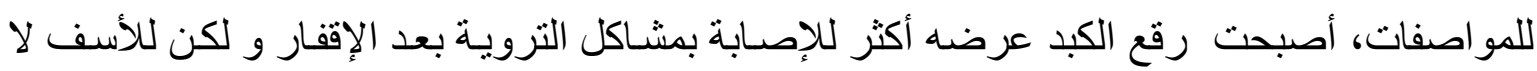

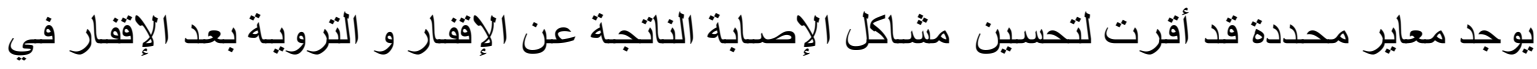
الكبد.

الهدف من البحث: تقييم دور التهيئة المسبقة للإققار على أضرار التروية بعد الإقفار فى كبد الجرذان المسنة.

مواد و طرق البحث: أجريت هذه الدراسة للتحقيق في التأثثر المحتمل للثرط الإقفاري المسبق ضد التبد إصابة نقص التروية الكبدية فى الجرذان المسنة.

أجريت هذه الدراسة على 45 جرذا ذكور، تم وزنهم و توزيعهم عشوائيا على ثنلاث مجموعات

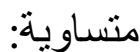

م المجموعة الأولى:جرذان هذه المجمو عة تعرضت لجر احة صورية ثم تم در استهم بعد 24 ساعة.

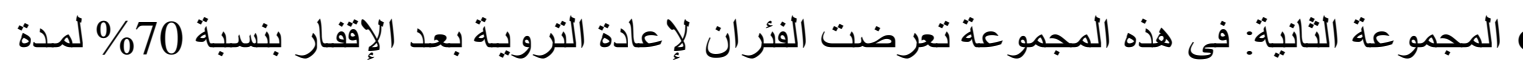

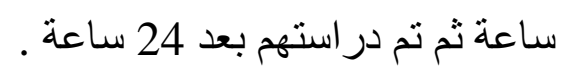
ه المجموعة الثالثة: جرذان هذه المجموعة تعرضت إلى التهيئة المسبقة قبل إعادة التروية بعد الإقفار

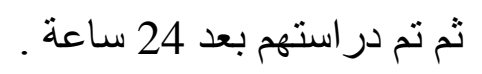

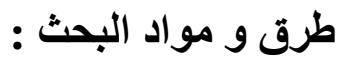
- و - وزن الكبد وحساب نسبة وزن الكبد الكبد إلى وزن الجسم.

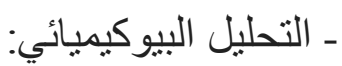
( أ ) أخذ عينة دم لفصل السيرم لدر اسة وقياس مستوى ALT و AST بعد سـاعة و 24 ساعة من

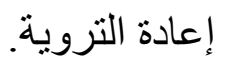
MDA فى نسيج الكبد. (ج) قياس مستوى الجلو ثاثيون بيروكسيديز GPx فى نسيج الكبد. 
كما نم إخضاع الكبد لدراسة الأنسجة بو اسطة المجر الضوئي.

في هذه الدراسـة، أظهرت جميع المجمو عات مقارنـة دـع المجموعة الأولى إنخفاضـا ذو دلالـة

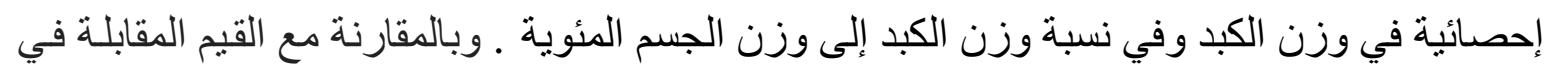

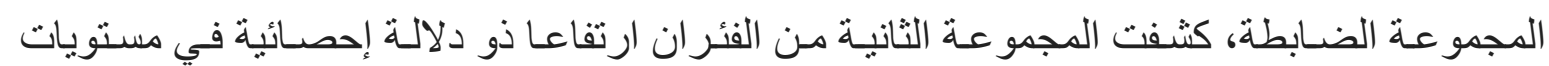
إنزيمات الكبد ALT و AST، في نقطتين زمنيتين، وخاصة بعد 24 ساعة وكذللك زيادة ذات دلالة

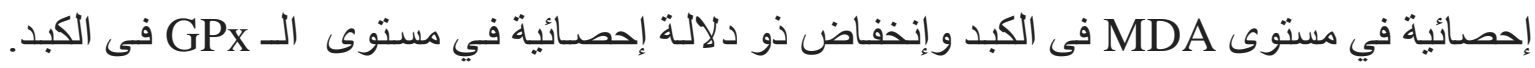

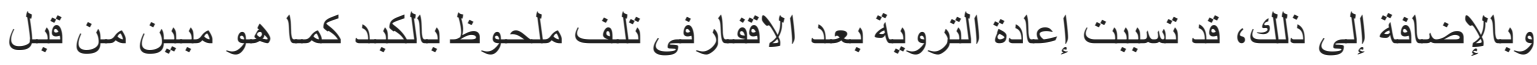
الفحص النسيجي المرضي.

و عند تعرض الجرذان إلى التهيئة المسبقة قبل إعادة الترويـة بعد الإققار فى المجموعة الثالثة ،

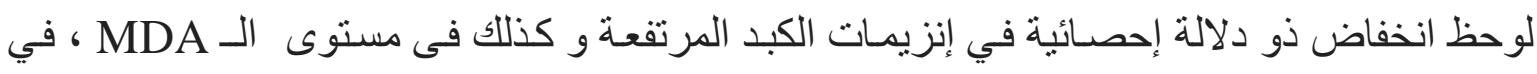

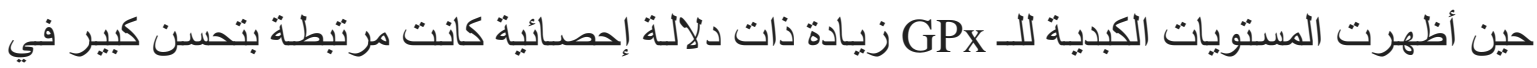
الدر اسة النسيجية مقارنة مع مجمو عة الثانية.

الإستنتاج: - (الإنة

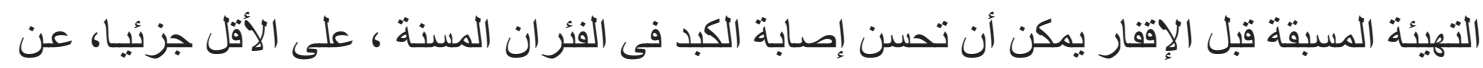

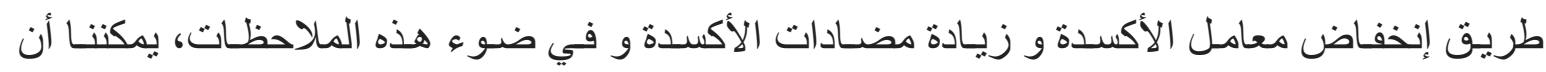

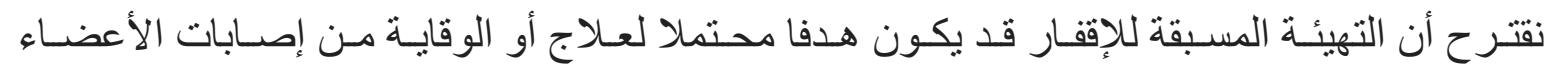
والأنسجة من قبل إعادة التروية قبل الإقفار ، ويمكن أن تكون واعدة فى زر اعة الأعضاء.

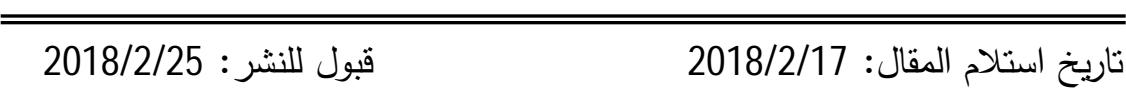

